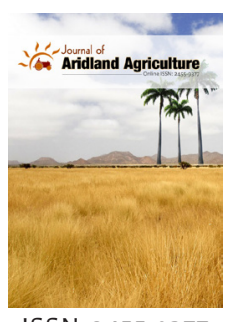

ISSN: $2455-9377$

\title{
The effect of zinc fertilization and cow dung on sterility and quantitative traits of rice
}

\author{
Mohammad Sohidul Islam ${ }^{1 *}$, Mst. Khaleda Khatun', ASM Golam Hafeez², \\ M. Kaium Chowdhury33, Ömer Konușkan4, Celaleddin Barutcular5, \\ Murat Erman ${ }^{6}$, Fatih Çiğ ${ }^{6}$, Ayman EL Sabagh ${ }^{6,7^{*}}$
}

'Department of Agronomy, Hajee Mohammad Danesh Science and Technology University, Dinajpur, Bangladesh, ${ }^{2}$ Department of Agricultural Finance, Bangladesh Agricultural University, Mymensingh, Bangladesh, ${ }^{3}$ Bangladesh Agricultural Training Institute (Department of Agricultural Extension), Gaibanda, Bnagladesh, ${ }^{4}$ Department of Field Crops, Faculty of Agriculture, Hatay Mustafa Kemal University, Hatay, Turkey, ${ }^{5}$ Department of Field Crops, Faculty of Agriculture, University of Çukurova, Turkey, ${ }^{6}$ Department of Field Crops, Faculty of Agriculture, Siirt University, Turkey, ${ }^{7}$ Department of Agronomy, Faculty of Agriculture, Kafrelsheikh University, Egypt

\begin{abstract}
The grain yield of rice is far below from its potential yield due low organic matter and micronutrients in the soil. Application of cow dung and zinc fertilizer increases grain yield and quality. A field experiment was, therefore, conducted to evaluate the effect of zinc fertilization and well decomposed cow dung on the spikelet sterility, yield, zinc concentration in grains and plants of aromatic rice (cv. Tulshimala). In this experiment, two levels of well decomposed cowd ung (CD) of 0,10 tha ${ }^{-1}$, and four doses of zinc fertilization viz. 0, 2.16, 4.32, $6.48 \mathrm{~kg} \mathrm{ha}^{-1}$ of zinc were used following eight treatment combinations. The experiment was laid out in a factorial randomized complete block design (RCBD) with replication thrice. The data revealed that zinc fertilization remarkably increased the grain yield of Tulshimala by reducing the spikelet sterility percentages in both conditions of CD and the efficiency of zinc fertilization was superior in manuring (CD) condition to non-manuring condition. However, zinc fertilization at the rate of $4.32 \mathrm{~kg} \mathrm{ha}^{-1}$ of zinc produced the maximum grain yields under manuring and non-manuring conditions. Zinc fertilization increased the concentration of $\mathrm{Zn}$ in the rice plants and grains without and with CD. The strong linear relationship between the grain yield and zinc concentration in the rice plants and grains was found with in this study. Zinc fertilization increased the grain yield and quality by decreasing sterility percentage under CD. Hence, for increasing productivity towards food security in future generation, integrated use organic and inorganic fertilizers should be used.
\end{abstract}

Ayman EL Sabagh

E-mail: ayman.elsabagh@agr. kfs.edu.eg

Mohammad Sohidul Islam

E-mail: shahid_sohana@

yahoo.com

KEYWORDS: Cow dung, Micronutrient (Zn), Yield, Nutrient content and uptake, Aromatic rice

\section{INTRODUCTION}

Rice (Oryza sativa L.) is one of the most important food grain crops of the world, and it is the second most widely consumed in the world after wheat (Rajamoorthy et al., 2015). There is a growing concern that current levels of rice and wheat production will not meet future demand. The world population is projected to increase from 7.21 billion in 2015 to 8.27 billion in 2030, indicating a corresponding increase in food demand from 680 million tons in 2015 to 771 million tons in 2030 (FAO, 2016). However, to meet this challenge of increased food demand, the production per unit area (productivity) per unit time has to be increased necessarily.

Intensive rice mono-cropping system which receive heavy applications of chemical fertilizers alone, leads to a slow decline in productivity. Not only that, indiscriminate use of high analysis chemical fertilizers leading to development of several problems like decline in soil organic matter, soil pollution, increase in salinity, severe attack of pest and diseases (Chakraborthi \& Singh, 2014). Due to these problems, organic farming has gained popularity in recent years. The demand for organic food is steadily increasing both in developed as well as developing countries with an annual growth rate of 20-25\%. Sahrawat (2004) confirmed that wetland rice culture favors fertility maintenance and buildup of organic matter in soils, and is the backbone of long-term sustainability of the wetland rice systems. Application of organic materials is fundamentally important in that they supply various kinds of plant nutrients including micronutrients, improve soil physical and chemical properties such as structure, porosity, permeability, cationexchange capacity, and hence nutrient holding and buffering capacity, consequently enhance 
microbial activities (Suzuki, 1997). In addition, organic matter continuously releases $\mathrm{N}$ as needed by plants.

In general, soils used for cereal production in the world containing low levels of plant available micronutrient, reduces not only grain yield, but also nutritional quality. Low fertile soils are brought under concentrated cultivation due to high population pressure. Micronutrient deficiency is being paid more attention in recent times in areas where intensive agriculture is practiced. Micronutrients depletion in soil have been accelerated by increase of intensive cultivation with increased dependence on inorganic fertilizer and decreasing emphasis on the use of organic manures as well as using of high yielding varieties. Among micronutrient deficiencies, zinc ( $\mathrm{Zn}$ ) deficiency has been identified as a most serious agricultural issue in the world (Meng et al., 2016). It has been reported that Zn deficiency occurs in neutral and calcareous soils, intensively cropped soils, paddy soils and very poorly drained soils, sodic and saline soils, peat soils, soils with high available P and Si status, sandy soils, highly weathered, acidic and coarse textured soils (Dobermann \& Fairhurst, 2000). The reduction of $\mathrm{SO}_{4}{ }^{2-}$ to $\mathrm{H}_{2} \mathrm{~S}$ in flooded soils further limits the availability of $\mathrm{Zn}$ and $\mathrm{Cu}$. Rice is one of highly sensitive crops to $\mathrm{Zn}$ deficiency, and $\mathrm{Zn}$ is the most important micronutrient limiting rice growth and yield. Moreover, rice grown in flooded conditions has higher requirement of $\mathrm{Zn}$, because of the availability of other nutrients in submerged condition increases which decreases the $\mathrm{Zn}$ availability to crop (Fageria et al., 2002). In rice, low plant-available Zn in soil causes leaf bronzing and poor tillering at the early growth stages, leading to delayed maturity and significant yield loss (Neue et al., 1998; Dobermann \& Fairhurst, 2000). The main cause of deficiency of plant available $\mathrm{Zn}$ in soil is the precipitation or adsorption of $\mathrm{Zn}$ with various soil components, depending on the soil $\mathrm{pH}$ and redox potential (Impa \& Johnson-Beebout, 2012).

Zinc deficiency is a well known nutritional and health problem in human populations where rice is the dominating staple food crop (Stein, 2010). More than one-third of the world's population suffers from Zn deficiency (Hotz \& Brown, 2004; Stein et al., 2007). In humans, Zn deficiency-induced malnutrition adversely affects overall growth, leading to stunting in children, susceptibility to infectious diseases, iron deficiency anaemia, and poor birth outcome in pregnant women (Prasad, 2009; Graham et al., 2012), diarrhea and pneumonia in children (Graham et al., 2001; Fischer et al., 2007; Black et al., 2008). However, the lack of diversity in the diet and poor-quality foods with routine consumption of cereal-based staples is the main causes of Zn deficiency in humans (Pfeiffer \& McClafferty, 2007). The availability of internal $\mathrm{Zn}$ distribution in crop plants are increased phloem mobility and root to-shoot $\mathrm{Zn}$ translocation, sub-cellular Zn compartmentation, and biochemical use of Zn (Hacisalihoglu \& Kochian, 2003; White \& Broadley, 2011). One of the intercessions that have been proposed to overcome $\mathrm{Zn}$ deficiency in humans is the bio-fortification of staple foods with $\mathrm{Zn}$ during their natural growth cycle, through agronomic practices or genetic manipulations (Cakmak, 2008; White \& Broadley, 2009). Zinc deficiency in soil is usually corrected by the application Zn containing fertilizers like zinc sulfate. The use of organic manures alone may not be enough to meet the enormous nutrient requirements of present day high yielding cultivars. Hence, there is a lot of potential for use of cow dung with the inorganic fertilizer schedule of rice and to reduce total dependence on inorganic fertilizers. Therefore, an integrated nutrient management in which both organic manures and inorganic fertilizers are used simultaneously has been suggested as the most effective method to maintain a healthy and sustainable soil system while increasing crop productivity. Keeping in view the importance of the mobility of nutrients, and zinc use efficiency in rice, a field experiment was conducted to study the effect of cow dung and zinc fertilization on the sterility percentage, yield, and nutrient concentration in the rice plants and grains.

\section{MATERIALS AND METHODS}

\section{Location and Duration}

Afield experiment was conducted at the Agronomy Research Filed, Hajee Mohammad Danesh Science and Technology University (HSTU), Dinajpur, Bangladesh. Geographically the experimental site is located at $25^{\circ} 38^{\prime \prime} \mathrm{N}$ latitude and $88^{\circ} 4 \mathrm{l}^{\prime \prime} \mathrm{E}$ longitude at an altitude of $37.5 \mathrm{~m}$ above the mean sea level. The Agro Ecological Zone (AEZ) of the area is the Old Himalayan Piedmont Plain (AEZ-1) (FRG, 2012). The study was conducted during July-December (Aman season), 2016.

\section{Weather Condition}

The weather conditions of the experimental were recorded. The means of methodological information, like temperature (maximum, minimum and average temperature, ${ }^{\circ} \mathrm{C}$ ), rainfall $(\mathrm{mm})$, and relative humidity (\%) of the experimental site during the crop growing season are presented in the Table 1.

\section{Soil Characteristics in the Experimental Field}

The soil the experiment was sandy loam (sand 56\%). The land type was high land and general soil type was non-calcareous, brown floodplain soil with Ranisankal soil series. The soil of the experimental sites was analyzed before transplanting ofrice. The pre-seeding total soil nitrogen $(\mathrm{N})$ was $0.08 \%$, indicating a deficiency in soil N. Soil available K, Ca, and $\mathrm{Mg}$ were 0.10 , 2.48 , and $0.29 \mathrm{meq} 100 \mathrm{~g}^{-1}$ soil, and available $\mathrm{P}, \mathrm{S}, \mathrm{B}$, and $\mathrm{Zn}$ were $11.20,6.29,0.13$, and $0.55 \mathrm{ppm}$, respectively. Based on the critical levels of these plant nutrients, N, S, Mg, B, and Zn were low but $\mathrm{P}, \mathrm{K}$, and $\mathrm{Ca}$ were high. Soil $\mathrm{pH}$ was 5.41 and organic

Table 1: Monthly temperature, rainfall and relative humidity of the experimental site during the period from July to December, 2016

\begin{tabular}{lccccc}
\hline Months & \multicolumn{3}{c}{ Temperature $\left({ }^{\circ} \mathrm{C}\right)$} & Rainfall $(\mathrm{mm})$ & $\begin{array}{c}\text { Relative } \\
\text { humidity (\%) }\end{array}$ \\
\cline { 2 - 4 } & Minimum & Maximum & Average & & 90 \\
\hline July & 24.8 & 32.1 & 28.45 & 360.0 & 87 \\
August & 24.4 & 33.7 & 29.05 & 145.0 & 91 \\
September & 23.8 & 31.7 & 27.75 & 519.0 & 86 \\
October & 22.0 & 32.3 & 27.15 & 186.0 & 81 \\
November & 16.0 & 30.6 & 23.3 & 0.0 & 85 \\
December & 12.1 & 26.4 & 19.25 & 7.0 & \\
\hline
\end{tabular}


matter was $1.42 \%$. The morphological, physical, and chemical properties of the soil are presented in Table 2.

\section{Experimental Design and Treatments}

The experiment was laid out in the Randomized Complete Block Design (RCBD) with three replications. The two factorial experiment contains, factor A of two levels of cow dung (CD) viz. 0 , and $10 \mathrm{tha}^{-1}$, and factor B of four levels of zinc viz. 0, 2.16, 4.32 , and $6.48 \mathrm{~kg} \mathrm{ha}^{-1}$ as zinc sulphate were used as treatments. There were eight treatment combinations viz. $\mathrm{T}_{1}=\mathrm{CD}_{0} \times \mathrm{Zn}_{0}$, $\mathrm{T}_{2}=\mathrm{CD}_{0} \times \mathrm{Zn}_{1}, \mathrm{~T}_{3}=\mathrm{CD}_{0} \times \mathrm{Zn}_{2}, \mathrm{~T}_{4}=\mathrm{CD}_{0} \times \mathrm{Zn}_{3}, \mathrm{~T}_{5}=\mathrm{CD}_{1} \times$ $\mathrm{Zn}_{0}, \mathrm{~T}_{6}=\mathrm{CD}_{1} \times \mathrm{Zn}_{1}, \mathrm{~T}_{7}=\mathrm{CD}_{1} \times \mathrm{Zn}_{2}, \mathrm{~T}_{8}=\mathrm{CD}_{1} \times \mathrm{Zn}_{3}$. The total number of plots was $24(8 \times 3)$. The size of unit plot was $4.0 \mathrm{~m} \times 2.5 \mathrm{~m}$. The spacing between blocks and plots were $50 \mathrm{~cm}$ and $25 \mathrm{~cm}$, respectively.

\section{Application of Cowdung and its Composition}

Well decomposed CD was used in this experiment. The CD was applied before in individual plot, and thoroughly mixed with the soil during final land preparation. Generally, the CD contains $10-15 \%$ dry matter of fresh manure, $10-15 \%$ dry matter, $14.6 \%$ organic material, $0.30-0.45 \%$ total nitrogen, $0.15-0.25 \%$ total phosphorus, $0.05-0.15 \%$ total potassium, and biological oxygen demand 5 days (Miner \& Smith, 1975).

\section{Experimentation}

The recommended doses of urea, TSP, MoP and gypsum were applied@150, 120,100 and 110 kg ha ${ }^{-1}$, respectively. The TSP,

Table 2: Chemical properties of soil in the experimental field with the critical value and extraction methods

\begin{tabular}{|c|c|c|c|}
\hline Properties & Value (\%) & Critical value & Extraction methods \\
\hline $\begin{array}{l}\text { Soil pH } \\
(1: 1.25 \\
\left.\text { Soil: } \mathrm{H}_{2} \mathrm{O}\right)\end{array}$ & 5.41 & - & $\begin{array}{l}\text { Glass-electrode } \mathrm{pH} \text { meter } \\
\text { with } 1: 1.25 \text { soil-water ratios } \\
\text { (Page et al., 1982). }\end{array}$ \\
\hline Organic matter & 1.42 & - & $\begin{array}{l}\text { Wet oxidation method } \\
\text { (Black, 1965). Calculated by } \\
\text { Van Bemmelen factor } 1.73 \\
\text { (Piper, 1966). }\end{array}$ \\
\hline N (\%) & 0.08 & 0.10 & $\begin{array}{l}\text { Micro-Kjeldahl method } \\
\text { (Bremner \& Mulvaney, } \\
\text { 1982). }\end{array}$ \\
\hline $\begin{array}{l}\text { Available P } \\
\text { (ppm) }\end{array}$ & 11.20 & 8.0 & $\begin{array}{l}\text { Molybdate blue ascorbic acid } \\
\text { (Bray \& Kurtz, 1945). }\end{array}$ \\
\hline $\begin{array}{l}\text { Exchangeable K } \\
(\text { meq \%) }\end{array}$ & 0.10 & 0.08 & $\begin{array}{l}\text { Determined by Flame } \\
\text { photometer }\end{array}$ \\
\hline $\begin{array}{l}\text { Exchangeable } \\
\text { Ca (meq \%) }\end{array}$ & 2.48 & 2.0 & $\begin{array}{l}\text { Atomic absorption } \\
\text { spectrophotometer } \\
\text { (Knudsen et al., 1982). }\end{array}$ \\
\hline $\begin{array}{l}\text { Exchangeable } \\
\text { Mg (meq \%) }\end{array}$ & 0.29 & 0.5 & $\begin{array}{l}\text { Extractable method (Hunter, } \\
\text { 1974). }\end{array}$ \\
\hline $\begin{array}{l}\text { Available S } \\
\text { (ppm) }\end{array}$ & 6.29 & 8.0 & $\begin{array}{l}\text { Turbidity method using } \mathrm{BaCl}_{2} \\
\text { (Fox et al., 1964). }\end{array}$ \\
\hline $\begin{array}{l}\text { Available B } \\
\text { (ppm) }\end{array}$ & 0.13 & 0.16 & $\begin{array}{l}\text { Calcium chloride extraction } \\
\text { method (Page et al., 1982) }\end{array}$ \\
\hline $\begin{array}{l}\text { Available Zn } \\
(p p m)\end{array}$ & 0.55 & 0.60 & $\begin{array}{l}\text { Atomic Absorption } \\
\text { Spectrophotometer } \\
\text { (Lindsay, \& Norvell, 1978). }\end{array}$ \\
\hline
\end{tabular}

MoP and gypsum were applied to the plots as basal during final land preparation. Zinc was applied according to the treatment specification from the zinc sulphate containing $36 \% \mathrm{Zn}$. Urea was applied in three equal splits. Thirty day old seedlings were transplanted in the experimental plot. Intercultural operations like gap filling, weeding, irrigation and drainage were done as and when required to normal crop growth.

\section{Data collection}

\section{Sterility percentage}

Filled and unfilled (sterile) spikelets were counted separately from 10 randomly selected panicles from the net plot and per cent spikelet sterility was calculated by using the following formula.

$$
\text { Spikelet sterility } \%=\frac{\begin{array}{c}
\text { Number of sterile } \\
\text { spikelets panicle }
\end{array}}{\text { Total number of spikelets }_{\text {panicle }^{-1}(\text { filled }+ \text { non filled })}} \times 100
$$

\section{Grain Yield}

The crop harvested from each net plot was bundled up separately and allowed for drying in sun and threshed individually plot-wise by manually. Cleaning of the threshed out grain was done and then dried in sun till a constant weight in order to record final yield. Grain yields from the labeled hills were also added to the corresponding plot yields before expressing the final grain yield in $\mathrm{kg} \mathrm{ha}^{-1}$. Grain yield was recorded plot-wise on sundry basis. Grain yield was expressed on $12-14 \%$ moisture basis.

\section{Straw Yield}

Straw from the net plot of each treatment was dried in sun till a constant weight was arrived. The straw from the 10 labeled hills was included to the netplot yields before expressing the final straw yield in $\mathrm{kg} \mathrm{ha}^{-1}$. Straw yields were recorded plot-wise on sundry basis. Grain yield was expressed on 12-14\% moisture basis.

\section{Zinc Concentration}

At harvest, the dried rice grain and straw samples were prepared for $\mathrm{Zn}$ analyses with a milling machine with a sieve spacing of $0.7 \mathrm{~mm}$. Total $\mathrm{Zn}$ was determined using a nitric-per chloric acid digest with Atomic Absorption Spectrophotometer as per the procedure described by Prasad et al. (2006). Finally, the Zn concentrations in the dry weight of rice grain and straw were determined.

\section{Data Analysis}

All the data were statistically analyzed by Duncun's Multiple Range Test (DMRT) according to Gomez and Gomez (1984). 


\section{RESULTS AND DISCUSSION}

\section{Sterility Percentage}

The sterility percentage (SP) of grain is an important yield contributing trait which inversely related with the grain yield. In this study, the sterility percentage of rice was significantly influenced by CD and zinc sulphate (Figure 1). Application of organic manure (CD) with or without zinc sulpahte including recommended doses of chemical fertilizers (RDF) recorded the lowest SP as compared to control (No CD). On the other hand, zinc fertilization remarkably decreased the SP with or without CD. However, the lowest SP (5.62 and 13.67\%) was recorded at $4.32 \mathrm{kgha}^{-1}$ zinc sulphate and the highest (11.01 and 34.61\%) at control with and without $\mathrm{CD}$, respectively.

\section{Grain Yield (tha-1)}

The grain yield was significantly influenced by the application of $\mathrm{Zn}$, and the role of $\mathrm{Zn}$ to the grain yield was prominent with $\mathrm{CD}$ than without that. Zinc fertilization gradually increased the grain yield up to 4.32 zinc ha- ${ }^{-1}$ in both conditions of $\mathrm{CD}$, and thereafter decreased. However, the $\mathrm{Zn}_{2}$ treatment significantly produced the highest grain yields ( 2.79 and 2.32 tha $^{-1}$ ) with and without $\mathrm{CD}$ manuring, respectively. While the lowest grain yields $\left(1.80\right.$ and $\left.1.89 \mathrm{tha}^{-1}\right)$ were obtained from $\mathrm{Zn}_{0}$ treatment that was significantly lower than all other zinc treatments effect with and without CD, respectively (Figure 2). Manuring with CD increased the grain yield at all levels of zinc fertilization in this study.

\section{Straw Yield $\left(\mathrm{kg} \mathrm{ha}^{-1}\right)$}

The straw yield showed significant variations due to application of zinc fertilizer with organic manure, and the similar trends were also observed in case of straw yield as that of grain yield (Figure 3). Application of $\mathrm{Zn}$ recorded the increased straw yield ranging from 3.84-5.80 to 3.62-4.78 (t $\mathrm{ha}^{-1}$ ) which were augmented 22.92-51.04 and 16.02-32.04\% over control with and without $\mathrm{CD}$, respectively. However, the highest straw yield $\left(5.80 \mathrm{tha}^{-1}\right)$ was recorded at $\mathrm{Zn}_{2}$ treatment with $\mathrm{CD}$, while the lowest $\left(3.62\right.$ tha $^{-1}$ ) was recorded at $\mathrm{Zn}_{0}$ treatment without CD.

\section{Zinc Concentration in the Grain and Straw}

Zinc fertilization under CD or without CD significantly influenced the zinc concentration in the rice plant and grain (Figure 4). Application of zinc gradually increased the concentration of zinc in the rice plants and the values were more with CD manuring. However, the highest zinc concentration in the rice plants ( $42.74 \mathrm{ppm}$ ) was found in $\mathrm{CD}_{1} \mathrm{Zn}_{3}$ treatment which was at par with $\mathrm{CD}_{1} \mathrm{Zn}_{2}$ treatment combination. The similar trends were also observed in case of zinc concentration in the grain as that of zinc concentration in the rice plants (Figure 4). Rice plants contained more zinc than that in grain at all treatment conditions. However, the lowest zinc concentration (28.25 and $12.25 \mathrm{ppm}$ ) was found in $\mathrm{CD}_{0} \mathrm{Zn}_{0}$ treatment in the plants and grains, respectively (Figure 4 a \& b).

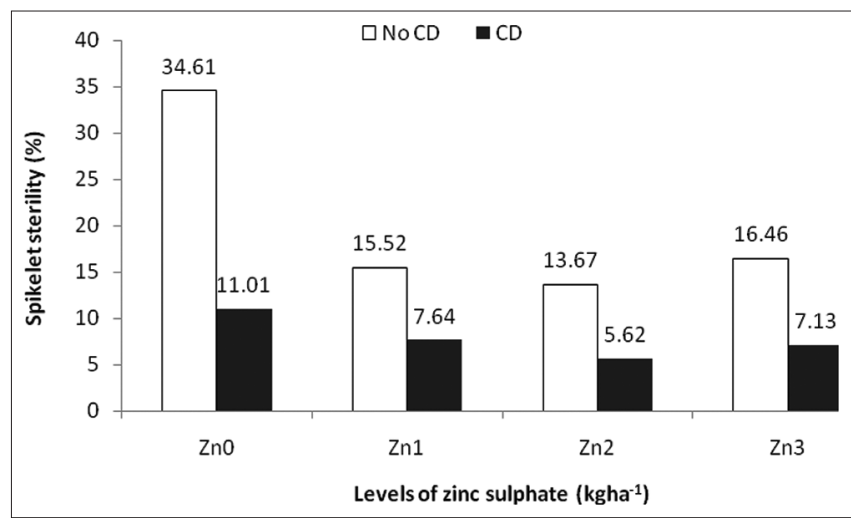

Figure 1: Effect of different levels of $C D$ and $Z n$ fertilization on the sterility percentages of aromatic rice (cv. Tulshimala)

$Z n_{0}=$ Control (No zinc fertilizer), $Z n_{1}=2.16 \mathrm{~kg} \mathrm{Zn} \mathrm{ha-1}^{-1}, Z n_{2}=4.32 \mathrm{~kg} \mathrm{Zn} \mathrm{ha-1}^{-1}$ and $Z \mathrm{n}_{3}=6.48 \mathrm{~kg} \mathrm{Zn} \mathrm{ha}^{-1}$, No $C D=$ No cow dung, $C D=$ Cow dung $\left(10 \mathrm{tha}^{-1}\right)$

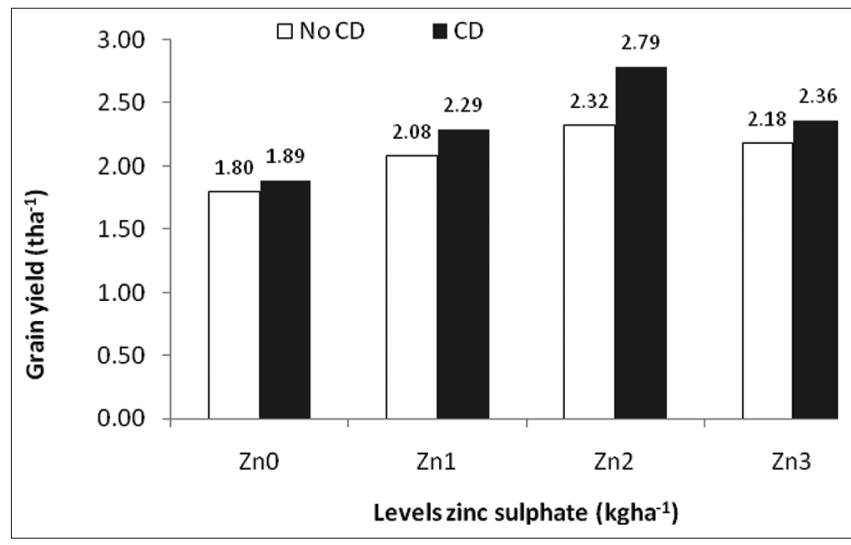

Figure 2: Effect of different levels of $C D$ and $Z n$ fertilization on the grain yield $\left(\right.$ tha $\left.^{-1}\right)$ ) of aromatic rice (cv. Tulshimala)

$Z n_{0}=$ Control (No zinc fertilizer), $Z n_{1}=2.16 \mathrm{~kg} \mathrm{Zn} \mathrm{ha}^{-1}, Z \mathrm{n}_{2}=4.32 \mathrm{~kg} \mathrm{Zn} \mathrm{ha}^{-1}$ and $Z n_{3}=6.48 \mathrm{~kg} \mathrm{Zn} \mathrm{ha}^{-1}$, No $C D=$ No cow dung, $C D=C o w$ dung $\left(10 \mathrm{tha}^{-1}\right)$

\section{Relationship between Grain Yield and Zinc Concentration (ppm)}

The linear relationship between grain yield and zinc concentration in rice plants was found significant having the regression analysis, $\mathrm{R}^{2}=0.742$ (Figure 5a). The regression equation of $\mathrm{x}$ (zinc concentration) on y (grain yield) was found to be $y=0.048 x+$ 0.463 which indicated that grain yield and $\mathrm{Zn}$ concentration (ppm) were positively related. The linear relationship between grain yield and zinc concentration in the rice grains was found similar trends as like grain yield and zinc concentration in rice plants with the regression analysis of $\mathrm{R}^{2}=0.720$ and the regression equation $\mathrm{y}=0.025 \mathrm{x}+1.537$ (Figure $5 \mathrm{Bb}$ ).

\section{DISCUSSION}

Application of zinc fertilization with and without CD remarkably decreased the percentages of sterile grains in this study (Figure 1). Foliar application of $\mathrm{Zn}$ has been reported to increase the viability of pollen grains ultimately reducing the sterility percentage (Karim et al., 2012). From the sterility point of view, the levels of $\mathrm{Zn}$ application contributed towards 


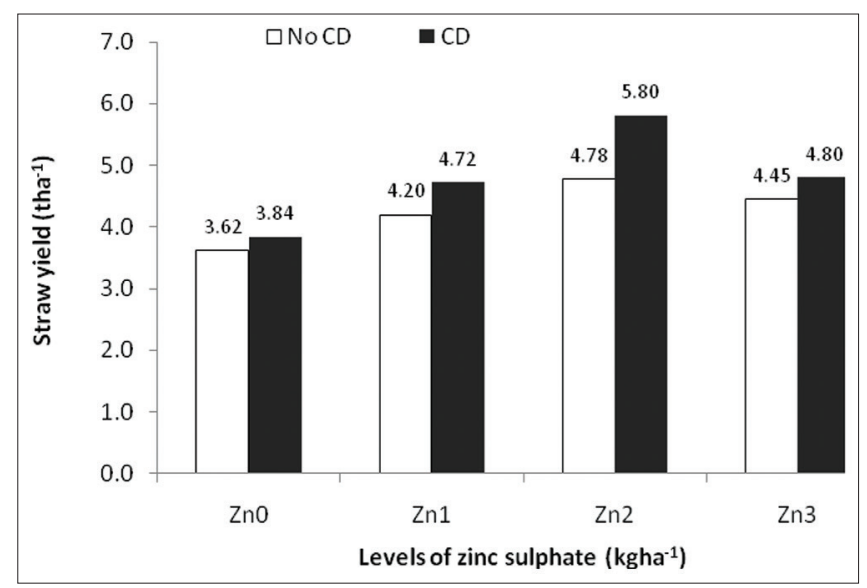

Figure 3: Effect of different levels of $C D$ and $Z n$ fertilization on the straw yield $\left(\right.$ tha $\left.\left.^{-1}\right)\right)$ of aromatic rice (cv. Tulshimala)

$Z_{0}=$ Control (No zinc fertilizer), $Z n_{1}=2.16 \mathrm{~kg} \mathrm{Zn} \mathrm{ha}^{-1}, Z_{2}=4.32 \mathrm{~kg} \mathrm{Zn} \mathrm{ha}^{-1}$ and $Z n_{3}=6.48 \mathrm{~kg} \mathrm{Zn} \mathrm{ha}^{-1}$, No $C D=$ No cow dung, $C D=$ Cow dung $\left(10 \mathrm{t} \mathrm{ha}^{-1}\right)$

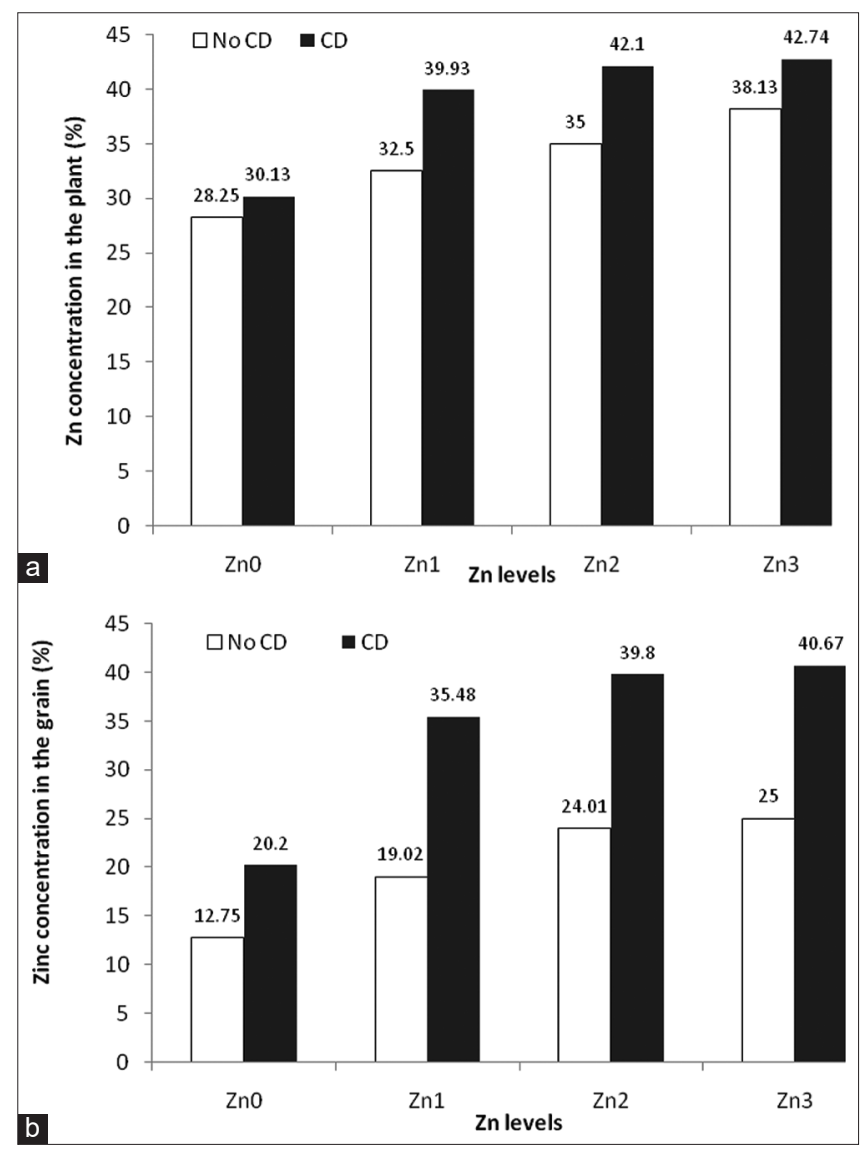

Figure 4: Effect of different levels of $C D$ and $Z n$ fertilization on the zinc concentration (ppm) in the rice plants (a) and grain (b)

$Z n_{0}=$ Control (No zinc fertilizer), $Z n_{1}=2.16 \mathrm{~kg} \mathrm{Zn} \mathrm{ha}^{-1}, Z_{2}=4.32 \mathrm{kgZn} \mathrm{ha}^{-1}$ and $Z n_{3}=6.48 \mathrm{~kg} \mathrm{Zn} \mathrm{ha}^{-1}$, No $C D=$ No cow dung, $C D=$ Cow dung $\left(10 \mathrm{tha}^{-1}\right)$

reducing the sterility percentage. The CD could bring about significant reduction in sterility percentage; the highest reduction was recorded in $\mathrm{Zn}_{2}$ treatment. The decreased number of chaffy grains and sterility per cent was noticed with the zinc micronutrient and CD. This may be due to higher accumulation

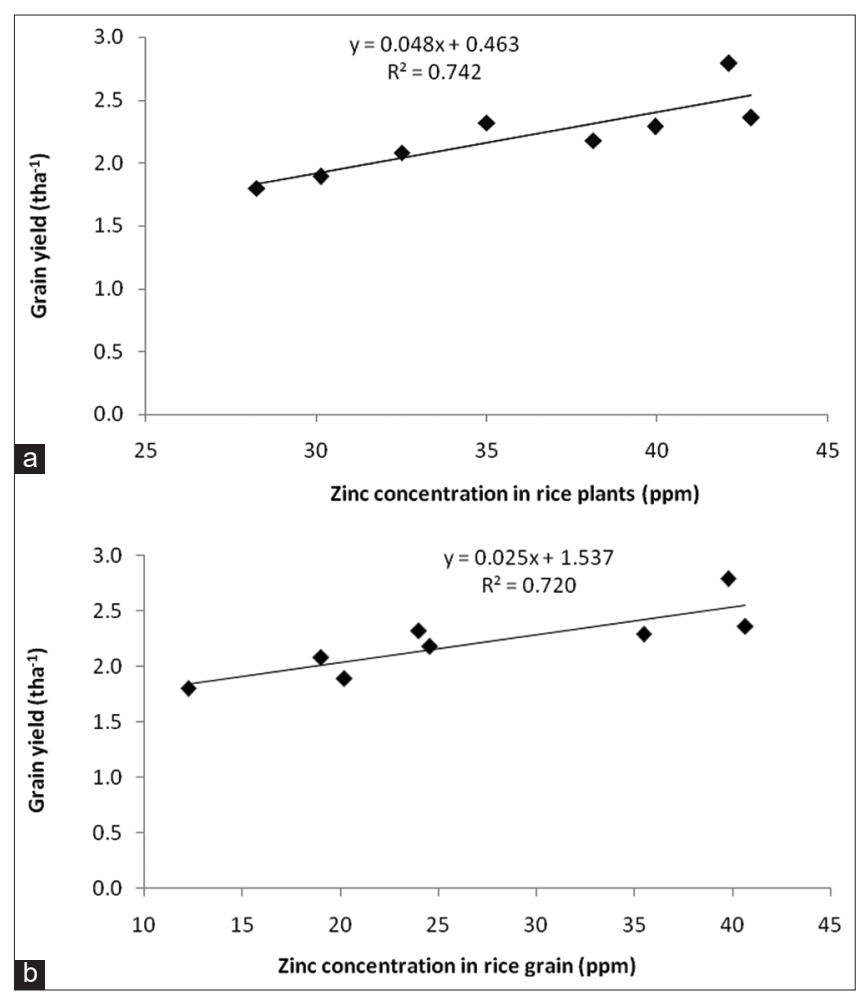

Figure 5: Relationship between grain yield and zinc concentration in plants (a) and grain (b) of aromatic rice (Tulshimala)

of nutrients might have helped in enhancing leaf area, which thereby resulted in better plant growth and more availability of photosynthesis for better grain filling under CD and zinc fertilization in the present trial.

The response of crop to different levels of zinc application, in terms of grain yield seems to be positive. Application of $\mathrm{Zn}$ is helpful for increasing the grain yield as reported by Khan et al. (2008) and Boorboori et al. (2012). The lowest grain yield was obtained in control condition of $\mathrm{Zn}$ and $\mathrm{CD}$ treatment with a yield loss of $55 \%$ compared to $\mathrm{Zn}_{2}$ with CD treatment (Figure 2). This might be due to unavailability of nutrients at later stages of crop growth from control plants. These findings are in agreement with that of Barik et al. (2006). The data on grain yield indicated that the grain yield was the highest when $\mathrm{Zn}_{2}$ was used with recommended dose of chemical fertilizer. It might be due to application of mineral $\mathrm{Zn}$ with $\mathrm{CD}$ recorded better growth and yield attributes which in turn increased the rice yields compared to control condition of $\mathrm{Zn}$ with and without $\mathrm{CD}$. The results of the investigation showed that organic manure significantly influenced the grain yield of paddy. The higher grain yield with organic manure might be due to additional nitrogen content in $\mathrm{CD}$ which is readily available as compared to control. The most notable thing is that the application of CD could improve affectivity of zinc fertilization and consequently increased the grain yield. It gives an inference that the level of $\mathrm{Zn}$ application into the soil at a rate of $4.32 \mathrm{~kg} \mathrm{Zn} \mathrm{ha}^{-1}$ under CD could be supposed to be better plant growth than the other treatment, resulting more grain yield. The higher yield associated with higher level of organic manures in combination with inorganic 
fertilizers may be due to its greater availability and uptake of macro- and micro-nutrients and active participation in carbon assimilation, photosynthesis, starch formation, translocation of protein and sugar, entry of water into plants root etc. Similar results were reported by Awad (2001) El-Refaee et al. (2006) and Ebaid \& El-Refaee (2007).

It also increased the activity of soil enzymes responsible for conservation of conversion of unavailable form of nutrient to available form and thereby increased grain yield (Singh et al., 2006; Kharub \& Chander, 2008; Gupta \& Sharma, 2010). Combined application of organic manure and zinc increased rice grain yield (Channabasavanna \& Biradar, 2001) which matched in this study. Organic manure also increased the rice grain yield with other inorganic fertilizers of $6 \mathrm{tha}^{-1}$ cowdung $+120 \mathrm{~kg} \mathrm{~N} \mathrm{ha}^{-1}$ (Hoshain, 2010), $10 \mathrm{t} \mathrm{ha}^{-1} \mathrm{CD}+45 \mathrm{~kg} \mathrm{~N} \mathrm{ha} \mathrm{k}^{-1}$, and $10 \mathrm{tha}^{-1} \mathrm{PM}$ (poultry manure) + $60 \mathrm{~kg} \mathrm{~N} \mathrm{ha}^{-1}$ (Rahman et al., 2009) and 3 t ha-1 PM $+80 \mathrm{~kg} \mathrm{~N} \mathrm{ha}{ }^{-1}$ (Nyalemegbe et al., 2009). Readily available nutrients in PM to the crop might have resulted in increased yield attributes and significant reduction in sterility per cent and there by resulted in higher yield as reported by Channabasavanna (2002), Hossan et al. (2010) and Sangeetha et al. (2010). Sharma and Mittra (1988) depicted that a combined use of organic manures and inorganic fertilizers checks nitrogen losses, conserves soil $\mathrm{N}$ by forming organic-mineral complexes and thus ensures continuous $\mathrm{N}$ availability to rice plants and greater yields. Separate and combined application of fertilizers and farmyard manure has shown long-term yield benefits, which have been attributed largely to the maintenance of soil organic matter and microbial activity (Ghoshal \& Singh, 1995). This CD might have helped to improve the soil physical, chemical and biological properties leading to overall improvement in soil health resulting higher yield. Similar views are expressed by Swarup (1987) and Mondal et al. (2003).

The straw yield under zinc treatment was superior over the control but the straw yield obtained under $\mathrm{Zn}_{1}$ and $\mathrm{Zn}_{3}$ were at par with each other (Figure 3). It has been reported that the straw yield increased with Zn application (Khan et al., 2008; Shaheen et al., 2007; Nai \& Das, 2010). It is noted here that application of $\mathrm{Zn}$ could significantly increase the straw yields with and without CD application, whereas CD exhibited higher straw yield with and without zinc application. The straw yield reduced by $11.02,17.59,7.29 \%$ only due to the lack of CD under zinc applied condition of $\mathrm{Zn}_{1}, \mathrm{Zn}_{2}$ and $\mathrm{Zn}_{3}$, respectively. Superior performance of CD might be due to the fact that it can supply the nutrients in soluble form for a quite longer period by not allowing the entire soluble form into solution, thereby minimizing the fixation and precipitation leading to better straw yield. The present findings corroborate with the findings of Mohandas et al. (2008) and Deshpande \& Devasenapathy (2011). Better performance of manure might be due to its higher macro- and micro-nutrients, growth hormones, antibiotics, enzymes, humic acid, beneficial microbes etc., which have better effect on the growth and yield of plants (Anitha et al., 2003).

Zinc concentration in the rice plants and grains significantly increased with the increasing levels of zinc fertilizers and CD, and the effects of zinc was more prominent under CD manuring
(Figure 4). The $\mathrm{Zn}$ concentration in the rice plant and grain ranged from 30.13 to 42.74 , and 20.20 to 40.67 ppm under CD manuring, and that of 28.25 to 38.13 , and 12.75 to $25 \mathrm{ppm}$ in non-manuring conditions, respectively. The increase in the zinc concentration in the rice plant and grain might be due to the presence of increased amount of $\mathrm{Zn}$ in soil solution by the application of zinc that facilitated greater absorption under CD manuring. The results revealed that the increase in $\mathrm{Zn}$ content was influenced by the application of cowdung, which are analogous with the results of Rana (2003) in BRRI dhan29. Similar results were observed by Islam (2004) who reported that application of organic manures and zinc fertilizer significantly increased the $\mathrm{Zn}$ content in rice straw. These results are in agreement with the findings of Islam (2004) and Hoque (1999) who reported that Zn concentration increased in rice grain by the addition of organic manures and zinc levels. Increase in $\mathrm{Zn}$ concentration in the rice plants and grains due to zinc fertilization was reported earlier (Mollah et al., 2009; Fageria et al., 2011). Similar result was reported by Naik and Das (2009).

The linear regression analysis indicated that $\mathrm{Zn}$ accounted for 74.2 and $72.0 \%$ variation in the grain yield of rice with the zinc concentration in rice plants and grains, respectively (Figure 5). This signifies the importance of sufficient availability of $\mathrm{Zn}$ in rice plants and grains which may amplify more rice growth and thereby more grain yield. Significant relationship between the grain yield and $\mathrm{Zn}$ concentration in rice (plants and grains) was also noticed by Nawaz et al. (2004), Hussain and Yasin (2004), Nathan et al., (2005) and Charati and Malakouti (2006). Increase in zinc concentration due to zinc application was reported by earlier workers (Naik \& Das, 2007; Rahmatullah et al., 2007; Chaudhary et al., 2007; Muthukumararaja \& Sriramachandrasekharan, 2012).

\section{CONCLUSION}

Based on the present study it can be conclusion that $\mathrm{Zn}$ application under manuring with CD decreased the sterility percentages of aromatic rice, and increased the yield of grain and straw. Application of zinc at the rate $4.32 \mathrm{~kg} \mathrm{ha}^{-1}$ as zinc sulphate produced the highest grain yield by brutal minimizing the sterility percentages of aromatic rice with and without CD manuring, and superior outcome was observed from CD manuring. Zinc concentration increased the rice grain as well as rice plants, which also showed sturdy linear relationship with the grain yield of studied cultivar Tulshimala. Hence, the treatment combination of CD $\mathrm{Zn}_{2}$ (Cow dung $10 \mathrm{tha}^{-1}+4.32 \mathrm{~kg} \mathrm{Zn} \mathrm{ha-1}$ i.e. $12 \mathrm{~kg} \mathrm{ZnSO}_{4}$ ) can be advised to apply for obtaining the maximum yield and superior grain quality (higher Zn content) of aromatic rice cv. Tulshimala. This study was conducted in the Old Himalayan Piedmont Plain (Agroeclogical zone-1) area and it should be repeated in different agro-climatic regions by using different levels of CD for final recommendation.

\section{ACKNOWLEDGEMENTS}

We thank to the under graduate students to conduct the research. We are also obliged to several colleagues for 
communicating valuable information, and they acknowledge the generous financial support by the University Grants Commission (UGC), Dhaka and also Institute of Research and Training (IRT), HSTU, Grant No. 4829.

\section{CONFLICT OF INTEREST}

The authors declare that they have no competing interests.

\section{SIGNIFICANCE STATEMENT}

The study ascertains the role of $\mathrm{Zn}$ under $\mathrm{CD}$ in wetland rice culture that can be beneficial for long-term sustainability of the wetland rice systems because availability of $\mathrm{Zn}$ in submerged condition decreases in rice crop and $\mathrm{Zn}$ deficiency has been identified as a most serious agricultural issue in the world. This study will help the researcher to uncover the $\mathrm{Zn}$ enrichment in rice grain with zinc fertilization under organic manuring that may researchers were not able to explore. Thus optimum doses Zn fertilization in wet land rice culture may be arrived here.

\section{REFERENCES}

Anitha, S., Jyothi, M. L., NarayananKutti, M. C., \& Nari, L. (2003). Evaluation of various organic manures as components in the integrated nutrient management of oriental pickling melon (Cucumis melo var. conomon). Progressive Horticulture, 35, 155-157.

Awad, H. A. (2001). Rice production at the North of Delta Region in Egypt as affected by irrigation intervals and nitrogen fertilizer levels. Journal Agricultural Science, Mansoura University, 26, 1151-1159.

Barik, A. K., Das, A., Giri, A. K., \& Chattopadhyay, G. N. (2006). Effect of organics (Vermicompost, farmyard manure) and chemical sources of plant nutrients on productivity and soil fertility of kharif rice (Oryza sativa L.). Crop Research, 31(3), 339-342.

Black, C. A. (1965). Methods of soil analysis, Part1, Agronomy Monograph 9.ASA Madison, Wisconsin, USA.

Black, R., Lindsay, H. A., Bhutta, Z. A., Caulfield, L. E., DeOnnis, M., Ezzat, M., Mathers, F., \& Rivera, J. (2008). Maternal and child under nutrition: global and regional exposures and health consequences. The Lancet, 371, 243-260. https://doi.org/10.1016/S0140-6736(07)61690-0

Boorboori, M. R., Eradatmand, A. D., \& Tehrani, M. (2012). The effect of dose and different methods of Iron, Zinc, Manganese and Copper application on yield components, morphological traits and grain protein percentage of barley plant (Hordeum vulgare L.) in greenhouse conditions. Advances in Environmental Biology, 6(2), 740. http://www.aensiweb.com/old/aeb/2012/740-746.pdf

Bray, R. H., \& Kurtz, L.T. (1945). Determination of total, organic, and available forms of phosphorus in soils. Soil Science, 59, 39-45. http://dx. doi. org/10.1097/00010694-194501000-00006

Bremner, J. M., \& Mulvaney, C. S. (1982). Methods of soil analysis, part 2 Chemical and Microbiological Properties. pp. 595-624.

Cakmak, I. (2008). Enrichment of cereal grains with zinc: Agronomic or genetic biofortification. Plant and Soil, 302, 1-17. https://doi. org/10.1007/s11104-007-9466-3

Chakraborthi, M., \& Singh, N. P. (2004). Bio-compost: A novel input to organic farming. Agrobios Newsletter, 2(8), 14-15.

Channabasavanna, A. S. (2002). Efficient Utilization of Poultry Manure with Inorganic Fertilizers in Wet Land Rice. Journal of Maharashtra Agricultural Universities, 27(3), 237-238.

Channabasavanna, A. S., \& Biradar, D. P. (2001). Yield and yield attributes of transplanted summer rice as influence by organic manures and zinc levels. Journal of Maharastra Agriculture University, 26(2), 170-172.

Charati, A., \& Malakouti, M. J. (2006). Effect of zinc and cadmium concentrations on the rates of their absorption by rice and on some growth characteristics of the plant (Oryza sativa L.) part 2: yield and composition. 18th world congress of soil science, Philadelphia, Pennsylvania, July 9-15, 2006, USA. pp. 155-173.

Chaudhary, S. K., Thakur, S. K., \& Pandey, A. K. (2007). Response of wetland rice (Oryza sativa L.) to nitrogen and zinc. Oryza, 44(1), 31-34.

Deshpande, H. H., \& Devasenapathy, P. (2011). Effect of different organic sources of nutrients and green manure on growth and yield parameters of rice (Oryza sativa L.) grown under lowland condition. Crop Research, 41(1/3), 1-5.

Dobermann, A., \& Fairhurst, T. (2000). Rice: nutrient disorders and nutrient management. Potash and Phosphate Institute, Potash and Phosphate Institute of Canada, and International Rice Research Institute, Philippines.

Ebaid, R. A., \& El-Refaee, I. S. (2007). Utilization of rice husk as an organic fertilizer to improve productivity and water use efficiency in rice fields. African Crop Science Conference Proceedings, 8, 1923-1928. https:// www.cabdirect.org/cabdirect/abstract/20103268527

El-Refaee, I. S., Ebaid, R. A., \& El-Rewiny, I. M. (2006). Performance of rice (Oryza sativa L.) plant under different water regimes and methods of planting. Alex. Journal of Agriculture Research, 51(2), 7-55.

Fageria, N. K., Baligar, V. C., \& Clark, R. B. (2002). Micronutrients in crop production. Advances in Agronomy. 77, 185-268. https://doi. org/10.1016/S0065-2113(02)77015-6

Fageria, N. K., Dos Santos, A. B., \& Cobucci, T. (2011). Zinc nutrition of lowland rice. Communications in Soil Science and Plant Analysis, $42,1719-1727$

FAO (Food and Agriculture Organization), (2016). Food and agricultural organization of the United Nations (FAO), FAO Statistical Database; 2016. Available: http://faostat.fao.org

Fischer, W. C. L., \& Black, R. E. (2007). Functional indicators for assessing zinc deficiency. Food and Nutrition Bulletin, 28(S3), S454-S479. https://doi.org/10.1177/15648265070283s305

Fox, R. L., Olson, R. A., \& Rhoades, H. F. (1964). Evaluating the sulfur status of soil by plants and soil tests. Soil Science of America Proceedings. 28, 243-246. https://doi.org/10.2136/ sssaj1964.03615995002800030031x

FRG (Fertilizer Recommendation Guide), (2012). Agroecological Regions of Bangladesh. In: Fertilizer Recommendation Guide. Bangladesh Agricultural Research Council, Farm Gate, Dhaka-1207, Bangladesh.

Ghoshal, N., \& Singh, K. P. (1995). Effects of Farmyard Manure and Inorganic Fertilizer on the dynamics of Soil Microbial Biomass in a Tropical Dry land Agroecosystem. Biology and Fertility Soils, 19(2-3), 231-238. https://doi.org/10.1007/bf00336165

Gomez, K. A., \& Gomez, A. A. (1984). Statistical Procedures for Agricultural Research. Int. Rice Res. Inst., John Wiley and Sons. New York, Chichester, Brisbane, Toronto, Singapore. p. 680.

Graham, R. D., Knez, M., \& Welch, R. M. (2012). How much nutritional iron deficiency in humans globally is due to an underlying zinc deficiency? Advances in Agronomy, 115, 1-40. https://doi.org/10.1016/B978-012-394276-0.00001-9

Graham, R. D., Welch, R. M., \& Bouis, H. E. (2001). Addressing micronutrient malnutrition through enhancing the nutritional quality of staple foods: principles, perspectives and knowledge gaps. Advances in Agronomy, 70, 77-142. https://doi.org/10.1016/S0065-2113(01)70004-1

Gupta, V., \& Sharma, R. S. (2010). Effect of integrated nutrient management on yield and nutrients uptake based cropping, conducted at Jabalpur (M.P.). Research on Crops, 11(2), 239-243.

Hacisalihoglu, G., \& Kochian, L. V. (2003). How do some plants tolerate low levels of soil zinc? Mechanisms of zinc efficiency in crop plants. New Phytologist, 159, 341-350. https://doi.org/10.1046/j.14698137.2003.00826.x

Hoque, M. A. (1999). Response of S, Zn and B supplied from manures and fertilizers on BRRI dhan29. An MS thesis, Dept. of Soil Science, Bangladesh Agricultural University, Mymensingh, Bangladesh.

Hoshain, S. (2010). Effect of cow dung and nitrogen (urea) on growth, yield and yield contributing characters of aromatic rice cV. BRRI dhan50. MS Thesis. Dept. Agron., Bangladesh Agricultural University, Mymensingh, Bangladesh. pp. 4-20.

Hossan, A. T. M. S., Rahman, F., Saha, P. K., \& Solaiman, A. R. M. (2010). Effects of different aged poultry litter on the yield and nutrient balance in boro rice cultivation. Bangladesh Journal of Agricultural Research, 35(3), 497-505. https://doi.org/10.3329/bjar.v35i3.6456

Hotz, C., \& Brown, K. H. (2004). Assessment of the risk of zinc deficiency in populations and options for its control. Food and Nutrition Bulletin, 25, 194-204. https://doi.org/10.1177/15648265040251S205

Hunter, A. H. (1974). Tentative ISFEJ soil extractant procedure: International soil fertility evaluation and improvement project. Raleigh: North Carolina State University, USA. 
Hussain, F., \& Yasin, M. (2004). Soil fertility monitoring and management in rice-wheat system. Annual report LRRP, NARC, Islamabad, Pakistan. pp. 1-33.

Impa, S. M., \& Johnson-Beebout, S. E. (2012). Mitigating zinc deficiency and achieving high grain $\mathrm{Zn}$ in rice through integration of soil chemistry and plant physiology research. Plant and Soil, 361, 3-41. https://doi. org/10.1007/s11104-012-1315-3

Islam, M. S. (2004). Yield and yield attributes of transplanted aman rice (BRRI dhan30) as influenced by organic manures and zinc levels. M.S. Thesis, Dept. Agril. Chem., Bangladesh Agricultural University, Mymensingh, Bangladesh.

Karim, M. R., Zhang, Y. O., Zhao, R., Chen, X. P., Zhang, F. S., \& Zou, C. Q. (2012). Alleviation of drought stress in winter wheat by late foliar application of zinc, boron, and manganese. Journal of Plant Nutrition and Soil Science, 175, 142-151. https://doi.org/10.1002/ jpln.201100141

Khan, M. A., Fuller, M. P., \& Baluch, F. S. (2008). Effect of soil applied zinc sulphate on wheat (Triticum aestivum L.) grown on a calcareous soil in Pakistan. Cereal Research Communications, 36(4), 571-582. https:// doi.org/10.1556/CRC.36.2008.4.6

Kharub, A. S, \& Chander, S. (2008). Effect of organic farming on yield, quality and soil-fertility status under basmati rice (Oryza sativa)-wheat (Triticum aestivum) cropping system. Indian Journal of Agronomy, 53(3), 172-177. https://www.indianjournals.com/ijor.aspx?

Knudsen, D., Peterson, G. A., \& Pratt, P. F. (1982). Lithium, sodium and potassium determination. In Page, A. L., Miller, R. H., \& Keeney, D. R. (Eds). Methods of Soil Analysis, (Part-2, $2^{\text {nd }}$ eds). American Society of Agronomy, Madison, USA. pp. 228-239.

Lindsay, W. L., \& Norvell, W. A. (1978). Development of a DTPA soil test for Zn, Fe, Mn, and Cu. Soil Science Society of America Journal, 42, 421428. https://doi.org/10.2136/sssaj1978.03615995004200030009x

Meng, F. H., Liu, D., Yang, X. E., Shohag, M. J. I., Yang, J. C., Li, T. Q., Lu, L., \& Feng, Y. (2014). Zinc uptake kinetics in the low and highaffinity systems of two contrasting rice genotypes. Journal of Plant Nutrition and Soil Science, 177, 412-420. https://doi.org/10.1002/ jpln.201200621

Miner, J. R., \& Smith, R. S. (1975). Livestock waste management with pollution control. North Central Regional Research Publication 222, MWPS-19, Midwest Plan Service, lowa State University, Amnes, 1975, USA.

Mohandas, S., Paramasivam, V., \& Sakthivel, N. (2008). Phosphorus and zinc enriched organics for enhancing the yield of transplanted rice in new Cauvery delta. Tamil Nadu Journal of Ecobiology, 23, 73-76.

Mollah, M, Z. I., Talukder, N. M., Islam, M. N., \& Ferdous, Z. (2009). Effect of nutrients content in rice as influenced by zinc fertilization. World Applied Science Journal. 6(8), 1082-2009.

Mondal, S. S., Sitamgshu, S., Ghosh, A., \& Das, J. (2003). Response of summer rice (Oryza sativa L.) to different organic and inorganic sources of nutrients. Crop Research, 25(2), 219-222.

Muthukumararaja, T. M., \& Sriramachandrasekharan, M. V. (2012). Effect of zinc on yield, zinc nutrition and zinc use efficiency of lowland rice. Journal of Agricultural Technology, 8(2), 551-561.

Naik, S. K., \& Das, D. K. (2007). Effect of split application of zinc on yield of rice (Oryza sativa L.) in an Inceptisol. Archives of Agronomy and Soil Science, 53(3), 305-313.

Naik, S. K., \& Das, D. K. (2010). Evaluation of various zinc extractants in low land rice soil under the influence of zinc sulphate and chealated zinc. Communi. Communications in Soil Science and Plant Analysis. 41, 122-134. https://doi.org/10.1080/00103620903361674

Nathan, A. S., Norman, R. J., \& Wilson, C. E. (2005). Effect of zinc source and time of application time on zinc uptake and grain yiled of floodirrigated rice. Agronomy Journal, 97, 272-278.

Nawaz, M. S., Qasim, M., Bakhsh, A., \& Gurmani, A. H. (2004). Effect of zinc and copper fertilization on rice yield and soil/plant concentration. Pakistan Journal of Soil Science, 20, 13-18.

Neue, H. U., Quijano, C., Senadhira, D., \& Setter, T. (1998). Strategies for dealing with micronutrient disorders and salinity in lowland rice systems. Field Crops Research, 56, 139-155. https://doi.org/10.1016/
S0378-4290(97)00125-1

Nyalemegbe, K., Oteng, J. W., \& Asuming-Brempong, S. (2009). Integrated organic-inorganic fertilizer management for rice production on the vertisols of the accraplains of ghanak. West African Journal of Applied Ecology, 16(1), 23-32. https://doi.org/10.4314/wajae.v16i1.55866

Page, A. L., Miller, R. H., \& Keeney, D. R. (1982). Methods of soil analysis. Part 2, $2^{\text {nd }}$ ed., American Society of Agronomy. 677 South Segoe Road, Madison, Wisconsin, USA. https://doi.org/10.1002/jpln.19851480319

Pfeiffer, W. H., \& McClafferty, B. (2007). Harvestplus: breeding crops for better nutrition. Crop Science, 47, 88-105. https://doi.org/10.2135/ cropsci2007.09.0020IPBS

Piper, C. S. (1966). Soil and Plant Analysis. Adelaide University Press, Australia

Prasad, A. S. (2009). Impact of the discovery of human zinc deficiency on health. Journal American College Nutrition, 28, 257-265. https://doi. org/10.1080/07315724.2009.10719780

Prasad, R., Shivay, Y. S., Kumar, D., \& Sharma, S. N. (2006). Learning by doing exercise in soil fertility: A practical manual for soil fertility. Div. Agron., IARI, New Delhi. p. 68.

Rahman, M. S., Islam, M. R., Rahman, M. M., \& Hossain, M. I. (2009). Effect of cow dung, poultry manure, and urea on the yield and nutrient uptake of BRRI dhan29. Bangladesh Research Publication Journal, 2(2), 552-558

Rahmatullah, K., Gurmani, A. R., Sohailkhan, M., \& Hussain. A. (2007). Effect of zinc application on rice yield under wheat rice system. Pakistan Journal of Biological Sciences, 10(2), 235-239.

Rajamoorthy, Y., Rahim, K. B. A., \& Munusamy, S. (2015). Rice industry in Malaysia: challenges, policies and implications. Procedia Economics and Finance, 31, 861-867. https://doi.org/10.1016/S2212 5671(15)01183-1

Rana, M. M. (2003). Effect of cow dung with and without chemical fertilizers on yield protein and mineral composition in grain and straw of BRR dhan29. An MS thesis, Dept. of Agricultural Chemistry, Bangladesh Agricultural University, Mymensingh, Bangladesh.

Sahrawat, K. L. (2004). Organic matter accumulation in submerged soils. Advances in Agronomy. 81, 169-201. https://doi.org/10.1016/S00652113(03)81004-0

Sangeetha, S. P., Balakrishna, \& Bhuvaneshswari, J. (2010). Organic nutrient sources on growth and yield of rice. Madras Agricultural Journal, 97(7-9), 251-253.

Shaheen, R., Samim, M. K., \& Mahmud, R. (2007). Effect of zinc on yield and zinc uptake by wheat on some soils of Bangladesh. Journal of Soil and Nature. 1(1), 07-14.

Sharma, A. R., \& Mittra, B. N. (1988). Effect of combinations of organic materials and nitrogen-fertilizers on growth, yield and nitrogen uptake of rice. Journal of Agriculture Science, 111(3), 495-501.

Singh, R. P., Yadav, P. K., Singh, R. K., Singh, M. K., \& Singh, J. (2006). Effect of chemical fertilizers, FYM and biofertilizer on performance of rice and soil properties. Crop Research, 32, 283-285.

Stein, A. J. (2010). Global impacts of human mineral malnutrition. Plant and Soil, 335, 133-154. https://doi.org/10.1007/s11104-009-0228-2

Stein, A. J., Nestel, P., Meenakshi, J. V., Qaim, M., Sachdev, H. P. S., \& Bhutta, Z. A. (2007). Plant breeding to control zinc deficiency in India: how cost effective is biofortification. Public Health Nutrition, 106 , 492-501. https://doi.org/10.1017/S1368980007223857

Suzuki, A. (1997). Fertilization of rice in Japan. Japan FAO Association, Tokyo, Japan.

Swarup, A. (1987). Effect of presubmergence and green manuring (Sesbania aculeata) on nutrition and yield of wetland rice (Oryza sativa) on a sodic soil. Biology and Fertility Soils. 5(3), 203-208. https://doi. org/10.1007/BF00256901

White, P. J., \& Broadley, M. R. (2009). Biofortification of crops with seven mineral elements often lacking in human diets-iron, zinc, copper, calcium, magnesium, selenium and iodine. New Phytologist, 182 49-84. https://doi.org/10.1111/j.1469-8137.2008.02738.x

White, P. J., \& Broadley, M. R. (2011). Physiological limits to Zn biofortification of edible crops. Frontiers in Plant Science, 80(2), 1-11. https://doi.org/10.3389/fpls.2011.00080 